\title{
Evaluation of Economic Security of Water Resources and Analysis of Influencing Factors
}

\author{
Licheng Peng, Fujian Normal University, China \\ Xiaowei Ma, Fujian Normal University, China \\ Wanwan Ma, Shanghai University, China \\ Yuanxiang Zhou, Anhui University of Finance and Economics, China
}

\begin{abstract}
To effectively evaluate the level of economic security of water resources (WES) in China and analyze its influencing factors, a comprehensive evaluation model of WES and a regression analysis model of influencing factors are established based on the panel data of 30 provinces in China from 2011 to 2017. It is found that, first, WES in China presents a fluctuating upward trend. Second, different regions have different economic security levels for their water resources in China, among which WES in the central region is the highest. Third, there is a U-shaped correlation between economic development and WES, and the population, pollution control level, technological innovation have negative impacts on WES. Moreover, this study also finds that with upgrades to the industrial structure and level of human capital, there will be improvements to WES. However, the external coefficient and the investment scale of fixed assets have a negative impact on the economic security of water resources. This is helpful to utilize the water resources and improve the water resource safety management.
\end{abstract}

\section{KEYWORDS}

Economic Security, Fuzzy Comprehensive Evaluation, Influencing Factors, Water Resources

\section{INTRODUCTION}

At present, the international environment is constantly changing; thus, economic security has become increasingly complex. There has been a significant amount of research on economic security in China and the world. Traditional economic security mainly refers to the security of national natural resources supply and resources transportation channel. With the acceleration of global economic integration, the concept of economic security has gradually changed, placing the ability to resist external economic interference at the forefront while simultaneously placing more emphasis on the stability of market operations, including improvements to the market scale and structure. With the development of the national non-traditional security theory, the theme of security research has gradually become more profound, such that the topics of environmental security, energy security, ecological security, and financial security have begun to attract increasing attention (Sun et al., 2021; Fu et al., 2021). As the material basis of economic and social development, natural resources, directly affect national economic security, are the basic source of human production and life, and are fundamentally guaranteed in 
the sustainable development of the national economy (Song et al., 2020; Zhao et al., 2019a; Zhao et al., 2019b). As a type of non-traditional security, economic security from the perspective of natural resource assets has received increased attention from all demographics; however, this issue still requires further research.

Water resource demand is the basic demand for human survival and economic and social development. Within the background of continuous population growth and rapid socio-economic development, water resources security problems, such as water shortages and deterioration of the water ecological environment, have become increasingly prominent and, seriously threatens the security of water resources (Ginkel et al., 2018). Water resources security is an important topic in the field of resource security, as well as an important part of national economic security. Moreover, it is an important basis for national political and economic security, social stability, ecological environment security, and food security, and has a significant impact on the sustainable development of the regional economy, resources, and environment (Xenarios et al., 2021). With the development of industrialization and urbanization, the demand for water resources in various industries is increasing, which aggravates the contradiction between economic development and water resources protection globally. Comprehensively coordinating the relationship between economic development and water resources protection while promoting the security of human society and the water resources system can not only strengthen environmental protection, but also contribute to the construction of an ecological civilization in China and the world (Ako et al., 2010). The connotation of water resources security is diverse, covering many aspects of the economy, environment, society, and ecology, where the economic security of water resources is of great significance. Reasonable evaluation and influencing factor analysis of the economic security level of water resources is conducive for water resources management departments to understand current regional economic security of water resources and the regulation changes. It helps to create development plans that reflect the actual situation, improve the utilization efficiency of water resources, optimize water resources allocation, and holistically improve the economic security level of water resources. The study of economic security of water resources is of great significance to promote the rational use of water resources, realize harmonious development between water resources and economic society, and improve the level of water resources security management.

However, at present, most existing literature focuses on the connotation of water resources security and water resources security evaluation; relatively few studies focus on the economic security of water resources. Thus, evaluating the economic security of water resources and analyzing its influencing factors is of both theoretical and practical significance. The remainder of this paper is organized as follows. Section 2 reviews the relevant literature, Section 3 introduces the research methods and data sources, Section 4 analyzes the evaluation results for the economic security of water resources, Section 5 analyzes the factors influencing the economic security of water resources, and Section 6 provides our research conclusions.

\section{LITERATURE REVIEW}

\subsection{Connotation of Water Resources Security}

Earth's resources are limited; therefore, with advancement in industrialization, population growth, and economic development, the issue of resource security has received increasing attention. As a type of valuable strategic resource, water resources have increasingly become the supporting elements of economic growth (Chang and Zhu, 2021). Global changes such as urbanization, population growth, socio-economic changes, changing energy needs and climate change are putting unprecedented pressure on water resources (Mishra et al., 2021). Therefore, security of water resources has gradually become an urgent issue in academic research. There are numerous opinions on the definition of water resources security. Witter and Whiteford (1999) suggested that water resources security refers 
to having sufficient water of a certain quality to meet residential demand at an affordable price to maintain human health, safety, and welfare and production capacity. With the increasing prominence of environmental problems, people have realized that the excessive use of water resources will cause irreversible damage to the economy and society. At the Second World Water Resources Forum in 2000, the Global Water Partnership (2000) brought sustainable development issues, such as environmental protection and disaster control, into the scope of water resources security. Water resources security was defined as the ability for all to obtain sufficient water at an affordable price to maintain a clean, healthy, and happy life while ensuring the protection of and improvement to the environment, as well as the protection of vulnerable populations from water-related hazards (Global Water Partnership, 2000). Therefore, water resources security should at least include the following components: meeting basic needs, protecting the ecological environment, reasonable price, and reasonable management and control. With more robust academic research on water resources, the important factors of economic and social development have been included in the field of water resources security, such that the definition of water resources security has become interdisciplinary (Xenarios et al., 2021). In 2007, the United Nations defined water security as the ability of a population to obtain a sufficient quantity and quality of water to meet their livelihood, human well-being, and socio-economic development needs to ensure protection from water pollution and other water-related hazards, as well as to maintain ecosystems in an atmosphere of peace and political stability (UN, 2007). Grey and Sadoff (2007) extended the connotation of water resources security to the availability of an appropriate water quality and quantity required to maintain human health, life, ecology, and production, as well as the level of water-related risks that humans, the environment, and the economy can sustain. Since the $21^{\text {st }}$ century, the U.S. government linked resource security with anti-terrorism, emphasizing the security of the water infrastructure. According to the U.S. Environmental Protection Agency (EPA), water resources security is intended to prevent and control pollution and terrorism (Staudinger et al., 2006). To protect water resources security, ensuring the safety of drinking water and water conservancy facilities through "guns, gates, and guards" is necessary (Staudinger et al., 2006).

\subsection{Evaluation of Water Resources Security}

Water resources security reflects the fact that the water resources in a country or region in a specific historical development stage can satisfy the needs of the national economy and social sustainable development based on the predictable level of technical, economic, and social development. This definition uses the principle of sustainable development and the condition of maintaining the ecological environmental cycle such that there is a balance between the supply and demand of water resources. The principle of water resources security is that the supply of water resources can meet the reasonable demand for water resources, which involves social security, economic security, ecological security, and other aspects of human production and life (Mishra et al., 2021). Water resources security emphasizes that domestic water is a basic human right; everyone must have the right to safe water utilization. Scientific and objective evaluations of water resources security are an important component of research on water resources security; evaluations are also a basic research object to solve the problem of coordinated development of the economy, society, and ecological environment (Osei et al., 2010; Haider et al. 2015; Yin et al., 2020; Li et al., 2018). According to the characteristics of the water resource system, Van Leeuwen et al. (2012) proposed the concepts of the water resources security index and pressure index, constructing the water resources security evaluation index system. $\mathrm{Li}$ et al. (2020) established the evaluation index system for water resources security based on the four dimensions of water supply security, social security, economic security, and ecological security, analyzing the main influencing factors of the water resources security evaluation using a network analysis method. Meanwhile, combined with gray correlation analysis, they evaluated the situation of water resources security in Guizhou Province from 2008 to 2018. Sun et al. (2018) used the DPSIR (driving forces-pressure-state-impact-responses) conceptual model to evaluate the level of water resources security in Guizhou Province from 2005 to 2012, and found that except for droughts 
in 2006 and 2011, the water resources in other years had an "overall security" status. Drought has a significant influence on the water security in karst areas; such threats have also been exacerbated by the rapid development of Guizhou's economy, agricultural non-point source pollution, inadequate sewage treatment, and other factors.

\subsection{Review}

At present, there is relatively little research on the economic security of water resources; existing research mainly focuses on the connotation of water resources security and the evaluation of the water resources security level. Therefore, this study focuses on the evaluation of the level of economic security of water resources, and analyzes the factors influencing the economic security of water resources to provide theoretical support for the long-term development of the economic security of water resources in China. The main contributions of this study are as follows. First, we analyze the level of economic security of water resources in China with a unique research perspective, which enriches the relevant literature on water resources security. Second, based on the entropy method, we establish a fuzzy comprehensive evaluation model and analyze the situation of economic security of water resources in China, which provides a considerably important reference for the healthy development of China's resources economy. Third, based on the calculation of the level of economic security of water resources, we further examine its influencing factors, which provide theoretical support for China to formulate environmental regulation policies.

\section{RESEARCH METHODS AND DATA SOURCE}

\subsection{Fuzzy Comprehensive Evaluation}

When evaluating a system or object, there may be many relevant evaluation factors. Thus, a comprehensive evaluation based on multiple factors, instead of just one index, is necessary. If we suppose that $U=\left\{u_{1}, u_{2}, \cdots, u_{n}\right\}$ is a set of $n$ objects to be evaluated, and $V=\left\{v_{1}, v_{2}, \cdots, v_{m}\right\}$ is a set of evaluation factors, measuring each evaluation object in $U$ by each factor in $V$ can establish an observation matrix, $A$, as follows:

$$
A=\left[\begin{array}{cccc}
a_{11} & a_{12} & \cdots & a_{1 n} \\
a_{21} & a_{22} & \cdots & a_{2 n} \\
\cdots & \cdots & \cdots & \cdots \\
a_{m 1} & a_{m 2} & \cdots & a_{m n}
\end{array}\right],
$$

where $a_{i j}$ refers to the index value of the $j^{\text {th }}$ evaluation object under the $i^{\text {th }}$ evaluation factor. Vector $a_{j}=\left(a_{1 j}, a_{2 j}, \cdots, a_{m j}\right)^{T}(j=1,2, \cdots, n)$ indicates the evaluation vector of the $j^{\text {th }}$ evaluation object to $m$ indices.

To objectively and fairly evaluate each research object, the index value of each evaluation object will usually be dimensionless according to the index attribute; this index will then be weighted, establishing the objective function, followed by the calculation of the maximum or minimum value of the objective function. This is the fuzzy comprehensive evaluation method, whose main steps are as follows:

(1) Establish fuzzy benefit matrix 
In this study, the indices for the economic security of water resources were divided into two categories: positive index and negative index. The positive index, also known as the benefit index, states that the value of the index and the evaluation result are in the same direction: the larger the index value, the better the evaluation result. The negative index, also known as the cost index, refers to the negative relationship between the index value and evaluation result: the smaller the index value, the better the evaluation result. Owing to the varying attributes of the different indices and different measurement units, to facilitate analysis and comparison, this study established the fuzzy benefit matrix, B, through non-dimensionalization, transforming all the elements of the matrix into positive indices:

$$
\begin{aligned}
& B=\left(b_{i j}\right)_{m \times n} \\
& b_{i j}=\left\{\begin{array}{l}
\frac{a_{i j}-\min _{j} a_{i j}}{\max _{j} a_{i j}-\min _{j} a_{i j}} \text {, when } a_{i j} \text { is a positive index } \\
\frac{\max _{j} a_{i j}-a_{i j}}{\max _{j} a_{i j}-\min _{j} a_{i j}}, \text { when } a_{i j} \text { is an negative index }
\end{array}\right.
\end{aligned}
$$

(2) Establish weight vector, $w=\left(w_{1}, w_{2}, \cdots, w_{m}\right)$, for each evaluation index

The determination of the index weight can be divided into the subjective and objective weighting methods. The economic security of water resources involves resources, economy, ecological development, and other aspects. To ensure the objectivity of the evaluation results, we used the entropy method for objective weighting. Information entropy is a measure of the degree of system disorder, and information is a measure of the degree of system order. The absolute values of the two are equal; however, the symbols are opposite. The greater the degree of variation in an index value, the smaller is the information entropy; the greater the amount of information provided by the index, the greater the weight of the index. In contrast, the smaller the variation degree of an index value, the greater the information entropy; the smaller is the amount of information provided by the index, the smaller the weight of the index. Therefore, according to the variation degree of each index, we can use the information entropy tool to calculate the weight of each index.

(3) Establish the comprehensive evaluation model

$$
w_{e}=100 \sum_{j=1}^{p} w_{j} b_{i j},
$$

To better reflect the economic security level of water resources in a region, we use the hundredmark system to measure it. Where wes $_{i}$ refers to the level of economic security of water resources in each sample area. The maximum value of $w_{e} s_{i}$ is 100 , and the minimum value is 0 . The higher the $w_{i} s_{i}$ the higher is the level of economic security of water resources in the area. 


\subsection{Panel Data Regression Model}

The panel data regression model is usually used to analyze the influencing factors, and the general form is as follows:

$$
y_{i t}=\alpha_{0}+\sum_{i=1}^{n} \alpha_{i t} \cdot \text { control }_{i t}+\varepsilon_{i t} \text {, }
$$

where $y_{i t}$ refers to the explained variable and control $_{i t}$ and $\varepsilon_{i t}$ refer to each explanatory variable and the random disturbance term, respectively. Based on the panel data regression model, this study established a regression model for the factors influencing the economic security of water resources in China, as follows:

$$
\begin{aligned}
& \text { wes }_{i t}=\alpha_{0}+\alpha_{1} 1 n 2 p g d p+\alpha_{3} 1 n p g d p+\alpha_{4} 1 n p s+\alpha_{5} p l+\alpha_{6} t i \\
& +a_{7} i i s+\alpha_{8} i r s+a_{9} e f+\alpha_{10} f a s+\alpha_{11} h c+\varepsilon_{i t}
\end{aligned}
$$

where $w e s_{i t}$ refers to the explained variable, i.e., the level of economic security of water resources; the right side of the equation contains the relevant factors affecting the economic security of water resources; $\alpha_{i}$ is the to-be-estimated coefficient; $\varepsilon_{i t}$ indicates the random disturbance term; $i$ refers to area; and $t$ refers to a specific year.

\subsection{Index Selection and Data Source}

\subsubsection{Index System for Economic Security of Water Resources}

The principle of the economic security of water resources is whether the supply of water resources can meet the needs of social and economic development. The focus of the evaluation of economic security of water resources is not only limited to the status quo, but should also consider future possibilities. The content of the evaluation is not only the level of economic development, but also the status quo of the resources and environment. The main focus of the evaluation of economic security of water resources is whether the water resources of a country or a region can yield economic benefits, as well as whether it can conform to the needs of the long-term and sustainable development of the economy and society. Water resources security mainly emphasizes two aspects: one is that the quantity and quality of the water resources supply should meet the reasonable needs of human beings; the other is that the water resources supply of a country or a region should meet the requirements of its long-term economic and social development, as well as consider the economic cost and sustainable development ability. Therefore, combined with other studies on the economic security of water resources, we suggest that the connotation of the economic security of water resources should cover the acquisition and utilization of water resources. Thus, we defined the economic security of water resources as the state and ability of a country or region to obtain the required water resources stably, adequately and economically while reasonably developing and utilizing them to ensure the sustainable and healthy development of the economy and improvement to the comprehensive strength. The level of economic security of water resources reflects the stability of the above state or the strength in the ability, including the following four components: 1) Quantity security: the quantity of water resources in a country or a region can fully meet the demands for agricultural, industrial, domestic, and ecological water, among others. 2) Quality safety: the water resources of a country or region can yield high economic and social benefits while producing a low environmental pollution level. 3) Economic cost: the low construction cost of water resources facilities in a country or region. 4) Sustainable development capacity: a country or a region's good water resources development situation, strong sewage treatment capacity, flood control and disaster resistance capacity, and abundant talent reserves. Based on the above mentioned analysis, we comprehensively considered the current situation of the water resources utilization; economic development mode; data availability; and the scientific, systematic, and typical principles of the 
evaluation index system (Shi et al., 2017; Song et al., 2020b; Song et al., 2020c), finally establishing an index system for evaluating the economic security of water resources, including four criteria layers (quantity security, quality safety, economic cost, and sustainable development capacity) and 21 indices, as listed in Table 1. Quantity security mainly includes the water supply capacity and water demand. Among them, the storage of surface water and groundwater was selected for the supply capacity, whereas the water demand covers four aspects: agricultural water, industrial water, domestic water, and ecological environment water. Quality safety mainly includes the economic benefits of water resources and the cost of environmental pollution. For the economic benefit, the real GDP and per capita grain production were selected. The environmental cost included the urban sewage discharge, total wastewater discharge, chemical oxygen demand emissions, and pesticide usage. Economic cost mainly includes water saving and water conservancy facilities investments, which are respectively expressed by the total investments in urban water saving measures and completed investments in water conservancy construction. The sustainable development capacity of water resources is mainly measured by three aspects: sewage treatment capacity, flood control capacity, and talent reserve. Among them, the total sewage treatment capacity and urban sewage treatment rate were selected for the sewage treatment capacity; the total number of built reservoirs, length of dikes, and number of sluices were selected for the flood control capacity; and the total number of technical workers and the professional titles of these workers in the water department were selected for the talent reserve. Table 1 lists the attribute of each index.

\subsubsection{Index Selection of Influencing Factors}

Based on the calculation of the economic security of water resources in provinces and cities in China, we further investigated the factors influencing economic security of water resources. Therefore, in the analysis of the influencing factors, the dependent variable was the economic security level of water resources calculated in this study, expressed as wes. Following the principles of scientificity, operability, independence, and pertinence, this study selected the level of economic development (pgdp), population size (ps), pollution control level (pl), technological innovation level (ti), industrial structure upgrade level (iis), industrial structure rationalization level (irs), external coefficient (ef), fixed asset investment scale (fas), and human capital level (hc) as the influencing factors (Du et al., 2020). The level of economic development is measured by the regional per capita real GDP, where 2010 was used as the base period. To avoid drastic fluctuations in the data and eliminate possible heteroscedasticity, this study logarithmically processed the real per capita GDP, recorded as lnpgdp. Meanwhile, the square term of the economic development level was introduced and recorded as $\ln 2$ pgdp. The population size was expressed by the year-end number of permanent residents, which was similarly logarithmized and recorded as lnps. The level of pollution control was measured by the proportion of completed investments in industrial pollution control in GDP while the level of technological innovation was measured by the number of patents granted. The industrial structure upgrade index included industrial structure advancement (iis) and industrial structure rationalization (iis). The index of industrial structure advancement reflects the evolution process of a country's industrial structure from low to high levels according to the general law of economic development. This study used the industrial structure level coefficient to describe the evolution process of the three major industries at a quantity level based on the relative change in the share proportion. The specific calculation formula is $i i_{i t}=\sum_{m=1}^{3} y_{i m t} \cdot m$, where $y_{i m t}$ is the proportion of industry $\mathrm{m}$ in area $\mathrm{i}$ during year $t$. The rationalization of the industrial structure reflects the dynamic process of the continuous strengthening of the coordination ability and the continuous improvement in the correlation level among the industries in a country, reflecting the degree of coordination among industries and the effective utilization of resources. This study used the Theil index to measure the rationalization degree of the industrial structure in various provinces and cities. The specific calculation method is 
Table 1. Index system for the evaluation of the economic security of water resources

\begin{tabular}{|c|c|c|c|c|}
\hline Objective layer & $\begin{array}{l}\text { Criterion } \\
\text { layer }\end{array}$ & $\begin{array}{l}\text { Sub-criterion } \\
\text { layer }\end{array}$ & Index layer & $\begin{array}{c}\text { Index } \\
\text { attribute }\end{array}$ \\
\hline \multirow{21}{*}{$\begin{array}{l}\text { Economic } \\
\text { security of water } \\
\text { resources }\end{array}$} & \multirow{6}{*}{$\begin{array}{l}\text { A1: Quantity } \\
\text { security }\end{array}$} & \multirow{2}{*}{$\begin{array}{l}\text { B1: Supply } \\
\text { capacity }\end{array}$} & $\mathrm{C} 1$ : Surface water $\left(100\right.$ million $\left.\mathrm{m}^{3}\right)$ & Positive \\
\hline & & & $\begin{array}{l}\text { C2: Underground water (100 million } \\
\mathrm{m}^{3} \text { ) }\end{array}$ & Positive \\
\hline & & \multirow{4}{*}{$\begin{array}{l}\text { B2: Water } \\
\text { demand }\end{array}$} & $\begin{array}{l}\text { C3: Agricultural water (100 million } \\
\left.\mathrm{m}^{3}\right)\end{array}$ & Negative \\
\hline & & & C4: Industrial water $\left(100\right.$ million $\left.\mathrm{m}^{3}\right)$ & Negative \\
\hline & & & C4: Domestic water $\left(100\right.$ million $\left.\mathrm{m}^{3}\right)$ & Negative \\
\hline & & & $\begin{array}{l}\text { C6: Ecologic environmental water } \\
\left(100 \text { million } \mathrm{m}^{3}\right)\end{array}$ & Negative \\
\hline & \multirow{6}{*}{$\begin{array}{l}\text { A2: Quality } \\
\text { safety }\end{array}$} & \multirow{2}{*}{$\begin{array}{l}\text { B3: Economic } \\
\text { benefit }\end{array}$} & C7: Real GDP (CNY 100 million) & Positive \\
\hline & & & C8: Grain production per capita $(\mathrm{kg})$ & Positive \\
\hline & & \multirow{4}{*}{$\begin{array}{l}\text { B4: } \\
\text { Environmental } \\
\text { cost }\end{array}$} & $\begin{array}{l}\text { C9: Urban sewage discharge (10 } 000 \\
\left.\mathrm{~m}^{3}\right)\end{array}$ & Negative \\
\hline & & & $\begin{array}{l}\text { C10: Total wastewater discharge } \\
\text { (10000 tons) }\end{array}$ & Negative \\
\hline & & & $\begin{array}{l}\text { C11: Chemical oxygen demand } \\
\text { emission (10000 tons) }\end{array}$ & Negative \\
\hline & & & C12: Pesticide usage (10 000 tons) & Negative \\
\hline & \multirow{2}{*}{$\begin{array}{l}\text { A3: Economic } \\
\text { cost }\end{array}$} & $\begin{array}{l}\text { B5: Water } \\
\text { savings } \\
\text { investment }\end{array}$ & $\begin{array}{l}\text { C13: Total investment in urban water } \\
\text { saving measures (CNY } 10000)\end{array}$ & Negative \\
\hline & & $\begin{array}{l}\text { B6: Water } \\
\text { conservancy } \\
\text { investment }\end{array}$ & $\begin{array}{l}\text { C14: Completed investment of water } \\
\text { conservancy construction (CNY } 10 \\
000)\end{array}$ & Negative \\
\hline & \multirow{7}{*}{$\begin{array}{l}\text { A4: } \\
\text { Sustainable } \\
\text { development } \\
\text { capacity }\end{array}$} & \multirow{2}{*}{$\begin{array}{l}\text { B7: Sewage } \\
\text { treatment capacity }\end{array}$} & $\begin{array}{l}\text { C15: Total sewage treatment capacity } \\
\left(10000 \mathrm{~m}^{3} / \text { day }\right)\end{array}$ & Positive \\
\hline & & & C16: Urban sewage treatment rate $(\%)$ & Positive \\
\hline & & \multirow{3}{*}{$\begin{array}{l}\text { B8: Blood } \\
\text { control capacity }\end{array}$} & $\begin{array}{l}\text { C17: Total number of completed } \\
\text { reservoirs }\end{array}$ & Positive \\
\hline & & & C18: Dike length (km) & Positive \\
\hline & & & C19: Number of sluices & Positive \\
\hline & & \multirow{2}{*}{$\begin{array}{l}\text { B9: Talent } \\
\text { reserve }\end{array}$} & $\begin{array}{l}\text { C20: Total number of technical } \\
\text { workers in water department (person) }\end{array}$ & Positive \\
\hline & & & $\begin{array}{l}\text { C21: Total professional titles of } \\
\text { workers in water department (person) }\end{array}$ & Positive \\
\hline
\end{tabular}

$i r s_{i t}=1-\sum_{m=1}^{3} y_{i m t} \ln \left(y_{i m t} / l_{i m t}\right)$, where $y_{i m t}$ is the proportion of industry $\mathrm{m}$ in area $i$ during year $\mathrm{t}$ and $l_{i m t}$ represents the proportion of the employee number in industry $m$ in area $i$ during year $t$ of the number of total employees. The larger the value of the industrial structure rationalization, the more rational the industrial structure in a given region. The external coefficient was measured by the proportion of the total imports and exports in GDP; the scale of investments in fixed assets was 
measured by the proportion of investments in fixed assets in GDP; and the level of human capital was measured by the average number of college students per 100000 people.

\subsubsection{Data Source}

In the evaluation of the economic security of water resources, considering the index data availability, we used 30 provinces (autonomous regions and municipalities) in China from 2011 to 2017, except for Tibet, Hong Kong, Macao, and Taiwan, as the research objects. The data were obtained from the official website of the China National Bureau of Statistics and the easy professional superior (EPS) data platform. The real GDP was calculated from the GDP index, using 2010 as the base period. In the analysis of the influencing factors, data from 30 provinces (autonomous regions and municipalities) in China, except for Tibet, Hong Kong, Macao, and Taiwan, were collected, using 2011 to 2017 as the research period. The level of economic security of water resources in each province was measured in the previous section. Other data were obtained from the official website of the National Bureau of Statistics of China, the EPS data platform, and the China Statistical Yearbook for the corresponding years.

\section{RESULTS OF THE EVALUATION OF ECONOMIC SECURITY OF WATER RESOURCES}

\subsection{Index Weight}

According to Table 2, among the indices for the evaluation of economic security of water resources, the total investments in urban water saving measures, C13 had the largest weight, followed successively by the groundwater supply $\mathrm{C} 2$, and the urban sewage treatment rate $\mathrm{C} 16$ was the smallest.

\subsection{Economic Security of Water Resources}

The economic security levels of water resources in each area and the three regions from 2011 to 2017 are described in Table 3 and Figure 1, which indicate that the water resource security level had a fluctuating upward trend from the entire country and three regions' perspectives. This indicates that over time, there has been a gradual improvement in the economic security of water resources in China. Specifically, the level of economic security of water resources of the entire country from 2011 to 2017 increased from 49.22 to 51.68 , with a growth rate of $5.01 \%$. The level of economic security of water resources in the eastern region was the lowest among the three regions over the study period, which increased from 47.46 to 49.26 from 2011 and 2017, with a growth rate of $3.79 \%$. The economic security level of the water resources in the central region ranked first among the three regions for many years, which increased from 51.12 to 55.32 from 2011 and 2017, with a growth rate of $8.22 \%$. The level of economic security of water resources in the western region ranked second among the three regions, which increased from 49.60 to 51.47 from 2011 and 2017, with a growth rate of $3.78 \%$. Further observation on the economic security level of the water resources in various areas showed an upward trend in the economic security level of the water resources in most provinces and cities in China, especially in Jiangsu Province, where the economic security level of the water resources increased from 39.89 to 54.74 , with an overall growth of $37.22 \%$. Notably, although the economic security level of the water resources in most provinces and cities increased steadily, there were still many provinces and cities, such as Shanghai, Zhejiang, Fujian, Guangdong, Guangxi Zhuang Autonomous Region, Chongqing, and Yunnan, characterized by a decline in the level of economic security of water resources. This was especially evident for Guangdong Province in the eastern region, where the level of economic security of water resources declined from 47.80 to 34.69 , with an overall rate of $27.43 \%$. 
Table 2. Weight of each index

\begin{tabular}{|c|c|c|c|c|c|c|c|}
\hline Index & 2011 & 2012 & 2013 & 2014 & 2015 & 2016 & 2017 \\
\hline $\mathrm{C} 1$ & 0.0451 & 0.0448 & 0.0459 & 0.0451 & 0.0447 & 0.0449 & 0.0408 \\
\hline $\mathrm{C} 2$ & 0.0912 & 0.0900 & 0.0934 & 0.0911 & 0.0928 & 0.0960 & 0.0874 \\
\hline $\mathrm{C3}$ & 0.0422 & 0.0436 & 0.0447 & 0.0445 & 0.0442 & 0.0450 & 0.0407 \\
\hline $\mathrm{C4}$ & 0.0538 & 0.0520 & 0.0559 & 0.0581 & 0.0621 & 0.0662 & 0.0617 \\
\hline C5 & 0.0318 & 0.0340 & 0.0343 & 0.0334 & 0.0349 & 0.0349 & 0.0316 \\
\hline C6 & 0.0480 & 0.0465 & 0.0441 & 0.0381 & 0.0423 & 0.0481 & 0.0495 \\
\hline C7 & 0.0364 & 0.0342 & 0.0347 & 0.0338 & 0.0344 & 0.0349 & 0.0321 \\
\hline C8 & 0.0311 & 0.0306 & 0.0339 & 0.0341 & 0.0355 & 0.0359 & 0.0406 \\
\hline C9 & 0.0438 & 0.0413 & 0.0423 & 0.0401 & 0.0395 & 0.0407 & 0.0376 \\
\hline C10 & 0.0380 & 0.0360 & 0.0371 & 0.0361 & 0.0371 & 0.0383 & 0.0335 \\
\hline C11 & 0.0283 & 0.0268 & 0.0272 & 0.0263 & 0.0271 & 0.0273 & 0.0275 \\
\hline $\mathrm{C} 12$ & 0.0453 & 0.0428 & 0.0430 & 0.0416 & 0.0417 & 0.0428 & 0.0390 \\
\hline C13 & 0.1068 & 0.1318 & 0.1161 & 0.1372 & 0.1179 & 0.1020 & 0.1573 \\
\hline C14 & 0.0336 & 0.0318 & 0.0300 & 0.0294 & 0.0262 & 0.0212 & 0.0234 \\
\hline C15 & 0.0443 & 0.0414 & 0.0401 & 0.0400 & 0.0392 & 0.0399 & 0.0374 \\
\hline C16 & 0.0010 & 0.0007 & 0.0005 & 0.0005 & 0.0005 & 0.0002 & 0.0001 \\
\hline C17 & 0.0752 & 0.0742 & 0.0761 & 0.0747 & 0.0758 & 0.0770 & 0.0706 \\
\hline C18 & 0.0605 & 0.0673 & 0.0650 & 0.0608 & 0.0596 & 0.0587 & 0.0519 \\
\hline C19 & 0.0706 & 0.0792 & 0.0821 & 0.0804 & 0.0864 & 0.0891 & 0.0826 \\
\hline $\mathrm{C20}$ & 0.0319 & 0.0306 & 0.0330 & 0.0318 & 0.0344 & 0.0348 & 0.0336 \\
\hline $\mathrm{C} 21$ & 0.0409 & 0.0203 & 0.0206 & 0.0229 & 0.0237 & 0.0224 & 0.0211 \\
\hline
\end{tabular}

\section{ANALYSIS OF FACTORS INFLUENCING THE ECONOMIC SECURITY OF WATER RESOURCES}

\subsection{Descriptive Statistics}

Table 4 lists the results of the descriptive statistical analysis for each variable. According to Table 4 , the mean values of most variables are greater than the standard deviation, which indicates that the degree of data dispersion is not high; the variance expansion factors are significantly less than 10 , indicating that there is no multicollinearity between variables. In other words, we can use the existing data for further analysis.

\subsection{Unit Root Test}

To prevent the occurrence of pseudo regression, we tested the unit root of the explained variable and the core explanatory variable before regression to verify the robustness of the sequence. To ensure the robustness of the unit root test results, the Levin Lin Chu unit root test (LLC) and Fisher type unit root test (Fisher type unit root test) were used in this study, whose results are listed in Tables 5 and 6, respectively. According to the results of the unit root test, whether using the LLC or Fisher tests for the explained or explanatory variables, the original hypothesis of the unit root was rejected at the 5\% significance level. Therefore, the variables selected in this study were robust series, which could be used for regression analysis. 
Table 3. Level of economic security of water resources for each area of China from 2011 to 2017

\begin{tabular}{|c|c|c|c|c|c|c|c|c|c|}
\hline Area & 2011 & 2012 & 2013 & 2014 & 2015 & 2016 & 2017 & $\begin{array}{l}\text { Mean } \\
\text { value }\end{array}$ & Ranking \\
\hline Beijing & 44.20 & 43.55 & 40.35 & 39.33 & 42.33 & 37.71 & 46.71 & 42.03 & 30 \\
\hline Tianjin & 48.95 & 49.70 & 48.86 & 49.63 & 48.18 & 47.99 & 51.22 & 49.22 & 14 \\
\hline Hebei Province & 54.49 & 54.22 & 53.45 & 54.15 & 54.13 & 54.24 & 55.55 & 54.32 & 3 \\
\hline Liaoning Province & 46.50 & 50.14 & 45.70 & 47.58 & 45.48 & 47.58 & 52.39 & 47.91 & 24 \\
\hline Shanghai & 47.71 & 46.70 & 44.42 & 46.94 & 44.40 & 43.13 & 47.48 & 45.82 & 28 \\
\hline Jiangsu Province & 39.89 & 44.89 & 45.06 & 43.92 & 48.54 & 46.62 & 54.74 & 46.24 & 27 \\
\hline Zhejiang Province & 51.66 & 51.05 & 48.84 & 50.50 & 45.20 & 45.25 & 47.75 & 48.61 & 19 \\
\hline Fujian Province & 50.59 & 48.39 & 47.00 & 48.18 & 46.89 & 45.94 & 48.29 & 47.90 & 25 \\
\hline Shandong Province & 40.80 & 46.94 & 42.26 & 47.08 & 41.93 & 45.55 & 52.70 & 45.32 & 29 \\
\hline Guangdong Province & 47.80 & 51.23 & 50.36 & 50.57 & 48.69 & 42.68 & 34.69 & 46.57 & 26 \\
\hline Hainan Province & 49.47 & 48.81 & 47.51 & 48.69 & 47.17 & 46.78 & 50.34 & 48.40 & 20 \\
\hline $\begin{array}{l}\text { Mean value of eastern } \\
\text { region }\end{array}$ & 47.46 & 48.69 & 46.71 & 47.87 & 46.63 & 45.77 & 49.26 & 47.48 & (3) \\
\hline Shanxi Province & 50.62 & 51.91 & 50.00 & 50.52 & 49.88 & 50.13 & 53.36 & 50.92 & 10 \\
\hline Jilin Province & 49.34 & 51.92 & 51.32 & 52.00 & 50.34 & 51.50 & 55.16 & 51.66 & 8 \\
\hline Heilongjiang Province & 52.35 & 56.07 & 57.53 & 58.60 & 56.65 & 59.01 & 62.03 & 57.46 & 2 \\
\hline Anhui Province & 50.98 & 51.30 & 48.96 & 50.72 & 49.21 & 48.52 & 51.71 & 50.20 & 12 \\
\hline Jiangxi Province & 52.63 & 53.39 & 51.83 & 53.22 & 51.66 & 50.81 & 53.91 & 52.49 & 5 \\
\hline Henan Province & 49.29 & 51.78 & 52.44 & 53.59 & 52.34 & 51.80 & 53.86 & 52.16 & 6 \\
\hline Hubei Province & 47.28 & 50.95 & 50.11 & 52.57 & 50.33 & 49.16 & 53.64 & 50.58 & 11 \\
\hline Hunan Province & 56.44 & 59.04 & 57.56 & 59.03 & 57.54 & 57.42 & 58.85 & 57.99 & 1 \\
\hline $\begin{array}{l}\text { Mean value of central } \\
\text { region }\end{array}$ & 51.12 & 53.29 & 52.47 & 53.78 & 52.24 & 52.30 & 55.32 & 52.93 & (1) \\
\hline $\begin{array}{l}\text { Inner Mongolia } \\
\text { autonomous region }\end{array}$ & 50.46 & 52.14 & 51.12 & 52.58 & 51.23 & 51.04 & 53.23 & 51.69 & 7 \\
\hline $\begin{array}{l}\text { Guangxi Zhuang } \\
\text { autonomous region }\end{array}$ & 50.36 & 49.61 & 47.14 & 48.84 & 46.88 & 46.13 & 49.79 & 48.39 & 21 \\
\hline Chongqing & 50.21 & 48.16 & 46.55 & 48.38 & 47.56 & 46.84 & 50.09 & 48.26 & 22 \\
\hline Sichuan Province & 48.41 & 50.83 & 48.91 & 50.44 & 48.69 & 46.34 & 50.87 & 49.21 & 15 \\
\hline Guizhou Province & 45.75 & 48.88 & 47.86 & 48.80 & 47.74 & 46.70 & 49.75 & 47.92 & 23 \\
\hline Yunnan Province & 51.89 & 50.30 & 47.96 & 50.46 & 48.06 & 47.38 & 50.70 & 49.54 & 13 \\
\hline Shaanxi Province & 49.45 & 52.16 & 50.33 & 52.71 & 50.76 & 50.69 & 53.20 & 51.33 & 9 \\
\hline Gansu Province & 48.09 & 49.09 & 49.29 & 50.31 & 48.47 & 47.12 & 51.69 & 49.15 & 17 \\
\hline Qinghai Province & 50.50 & 49.58 & 48.29 & 49.38 & 48.18 & 47.60 & 50.95 & 49.21 & 16 \\
\hline $\begin{array}{l}\text { Ningxia Hui } \\
\text { autonomous region }\end{array}$ & 51.11 & 50.40 & 46.92 & 48.17 & 46.64 & 45.81 & 51.31 & 48.62 & 18 \\
\hline $\begin{array}{l}\text { Xinjiang Uygur } \\
\text { Autonomous Region }\end{array}$ & 49.31 & 55.23 & 52.71 & 55.39 & 54.70 & 54.41 & 54.57 & 53.76 & 4 \\
\hline $\begin{array}{l}\text { Mean value of western } \\
\text { region }\end{array}$ & 49.60 & 50.58 & 48.83 & 50.49 & 48.99 & 48.19 & 51.47 & 49.73 & (2) \\
\hline $\begin{array}{l}\text { Mean value of entire } \\
\text { country }\end{array}$ & 49.22 & 50.61 & 49.02 & 50.41 & 48.99 & 48.40 & 51.68 & 49.76 & \\
\hline
\end{tabular}


Figure 1. Level of economic security of water resources in China from 2011 to 2017

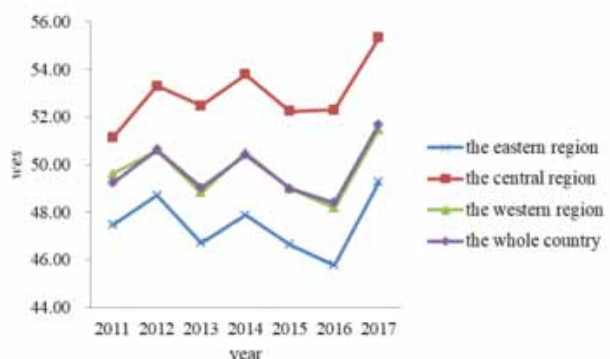

Table 4. Descriptive statistics of each variable

\begin{tabular}{|l|l|l|l|l|l|l|}
\hline \multicolumn{1}{|c|}{ Variable } & \multicolumn{1}{c|}{ Obs. } & \multicolumn{1}{c|}{ Mean } & \multicolumn{1}{c|}{ Std. Dev. } & \multicolumn{1}{c|}{ Min } & Max & VIF \\
\hline wes & 210 & 49.76 & 3.94 & 34.69 & 62.03 & - \\
\hline lnpgdp & 210 & 10.68 & 0.44 & 9.63 & 11.70 & 3.84 \\
\hline $\boldsymbol{l n p s}$ & 210 & 8.20 & 0.74 & 6.34 & 9.32 & 1.91 \\
\hline $\boldsymbol{p l}$ & 210 & 0.0013 & 0.0012 & 0.0001 & 0.0099 & 1.52 \\
\hline $\boldsymbol{t} \boldsymbol{i}$ & 210 & 44301.04 & 62420.25 & 502 & 332652 & 2.47 \\
\hline $\boldsymbol{i i s}$ & 210 & 2.35 & 0.13 & 2.17 & 2.80 & 4.05 \\
\hline $\boldsymbol{i r s}$ & 210 & 0.78 & 0.14 & 0.36 & 0.98 & 2.63 \\
\hline $\boldsymbol{e f}$ & 210 & 0.28 & 0.32 & 0.02 & 1.55 & 4.55 \\
\hline $\boldsymbol{f a s}$ & 210 & 0.79 & 0.24 & 0.24 & 1.48 & 2.63 \\
\hline $\boldsymbol{h} \boldsymbol{c}$ & 210 & 2533.09 & 809.46 & 1082.15 & 5612.87 & 2.63 \\
\hline
\end{tabular}

Table 5. LLC test results

\begin{tabular}{|l|l|l|l|}
\hline \multicolumn{1}{|c|}{ Variable } & \multicolumn{1}{c|}{ Adjusted t* } & \multicolumn{1}{c|}{ P-value } & Result \\
\hline wes & -12.0675 & 0.0000 & Robust \\
\hline lnpgdp & -16.2277 & 0.0000 & Robust \\
\hline $\boldsymbol{l n p s}$ & -3.1348 & 0.0008 & Robust \\
\hline $\boldsymbol{p l}$ & -8.4154 & 0.0000 & Robust \\
\hline $\boldsymbol{t i}$ & -9.3746 & 0.0000 & Robust \\
\hline $\boldsymbol{i} \boldsymbol{i} \boldsymbol{i r s}$ & -5.1726 & 0.0000 & Robust \\
\hline $\boldsymbol{e f}$ & -13.3017 & 0.0000 & Robust \\
\hline $\boldsymbol{f a s}$ & -9.8726 & 0.0000 & Robust \\
\hline $\boldsymbol{h} \boldsymbol{c}$ & -26.5989 & 0.0000 & Robust \\
\hline
\end{tabular}


Table 6. Fisher test results

\begin{tabular}{|c|c|c|c|c|c|}
\hline Variable & & & Statistic & p-value & Result \\
\hline \multirow{4}{*}{ wes } & Inverse chi-squared (60) & $\mathrm{P}$ & 126.1347 & 0.0000 & \multirow{4}{*}{ Robust } \\
\hline & Inverse normal & $\mathrm{Z}$ & -5.4000 & 0.0000 & \\
\hline & Inverse logit t (154) & $\mathrm{L}^{*}$ & -5.3352 & 0.0000 & \\
\hline & Modified inv. chi-squared Pm & $\mathrm{Pm}$ & 6.0372 & 0.0000 & \\
\hline \multirow{4}{*}{$\operatorname{lnpgdp}$} & Inverse chi-squared (60) & $\mathrm{P}$ & 106.6708 & 0.0002 & \multirow{4}{*}{ Robust } \\
\hline & Inverse normal & $\mathrm{Z}$ & -4.1173 & 0.0000 & \\
\hline & Inverse logit t (154) & $\mathrm{L}^{*}$ & -4.0737 & 0.0000 & \\
\hline & Modified inv. chi-squared Pm & $\mathrm{Pm}$ & 4.2604 & 0.0000 & \\
\hline \multirow{4}{*}{ lnps } & Inverse chi-squared (60) & $\mathrm{P}$ & 93.0499 & 0.0040 & \multirow{4}{*}{ Robust } \\
\hline & Inverse normal & $\mathrm{Z}$ & -3.0315 & 0.0012 & \\
\hline & Inverse logit t (154) & $\mathrm{L}^{*}$ & -2.9504 & 0.0018 & \\
\hline & Modified inv. chi-squared Pm & $\mathrm{Pm}$ & 3.0170 & 0.0013 & \\
\hline \multirow{4}{*}{$p l$} & Inverse chi-squared (60) & $\mathrm{P}$ & 131.1051 & 0.0000 & \multirow{4}{*}{ Robust } \\
\hline & Inverse normal & $\mathrm{Z}$ & -5.8665 & 0.0000 & \\
\hline & Inverse logit t (154) & $\mathrm{L}^{*}$ & -5.8836 & 0.0000 & \\
\hline & Modified inv. chi-squared Pm & $\mathrm{Pm}$ & 6.4910 & 0.0000 & \\
\hline \multirow{4}{*}{$t i$} & Inverse chi-squared (60) & $\mathrm{P}$ & 88.4569 & 0.0099 & \multirow{4}{*}{ Robust } \\
\hline & Inverse normal & $\mathrm{Z}$ & -3.3134 & 0.0005 & \\
\hline & Inverse logit t (154) & $\mathrm{L}^{*}$ & -3.1145 & 0.0011 & \\
\hline & Modified inv. chi-squared Pm & $\mathrm{Pm}$ & 2.5977 & 0.0047 & \\
\hline \multirow{4}{*}{ iis } & Inverse chi-squared (60) & $\mathrm{P}$ & 102.1005 & 0.0006 & \multirow{4}{*}{ Robust } \\
\hline & Inverse normal & $\mathrm{Z}$ & -4.3338 & 0.0000 & \\
\hline & Inverse logit t (154) & $\mathrm{L}^{*}$ & -4.1041 & 0.0000 & \\
\hline & Modified inv. chi-squared Pm & $\mathrm{Pm}$ & 3.8432 & 0.0001 & \\
\hline \multirow{4}{*}{ irs } & Inverse chi-squared (60) & $\mathrm{P}$ & 100.8939 & 0.0008 & \multirow{4}{*}{ Robust } \\
\hline & Inverse normal & $\mathrm{Z}$ & -4.2420 & 0.0000 & \\
\hline & Inverse logit t (154) & $\mathrm{L}^{*}$ & -4.0207 & 0.0000 & \\
\hline & Modified inv. chi-squared Pm & $\mathrm{Pm}$ & 3.7331 & 0.0001 & \\
\hline \multirow{4}{*}{$e f$} & Inverse chi-squared (60) & $\mathrm{P}$ & 92.1771 & 0.0048 & \multirow{4}{*}{ Robust } \\
\hline & Inverse normal & $\mathrm{Z}$ & -3.6917 & 0.0001 & \\
\hline & Inverse logit t (154) & $\mathrm{L}^{*}$ & -3.4667 & 0.0003 & \\
\hline & Modified inv. chi-squared Pm & $\mathrm{Pm}$ & 2.9374 & 0.0017 & \\
\hline \multirow{4}{*}{ fas } & Inverse chi-squared (60) & $\mathrm{P}$ & 89.3642 & 0.0083 & \multirow{4}{*}{ Robust } \\
\hline & Inverse normal & $\mathrm{Z}$ & -1.6602 & 0.0484 & \\
\hline & Inverse logit t (154) & $\mathrm{L}^{*}$ & -1.5774 & 0.0584 & \\
\hline & Modified inv. chi-squared Pm & $\mathrm{Pm}$ & 2.6806 & 0.0037 & \\
\hline \multirow{4}{*}{$h c$} & Inverse chi-squared (60) & $\mathrm{P}$ & 95.9362 & 0.0022 & \multirow{4}{*}{ Robust } \\
\hline & Inverse normal & $\mathrm{Z}$ & -2.5626 & 0.0052 & \\
\hline & Inverse logit t (154) & $\mathrm{L}^{*}$ & -2.4042 & 0.0087 & \\
\hline & Modified inv. chi-squared Pm & $\mathrm{Pm}$ & 3.2805 & 0.0005 & \\
\hline
\end{tabular}




\subsection{Model Selection and Results Analysis}

To analyze the influencing factors, three panel data regression models were established: mixed regression model, random effect model, and fixed effect model. To select a better regression model, several steps are usually required. First, mixed regression and random effect regression were performed, followed by the LM Test. If the results show that the original hypothesis is rejected, then there is a random disturbance term that reflects the individual characteristics in the original model, such that mixed regression should not be used. Then, the fixed effect regression and Hausman test were performed to determine whether to use the random effect model or fixed effect model. If the statistical test results show that the original hypothesis is rejected, the fixed effect model should be used; otherwise, the random effect model should be selected. Finally, if the fixed effect model is selected, the time effect in the model should also be considered to determine whether the two-way FE model should be selected, i.e., to test the joint significance of the annual dummy variables. If the original hypothesis of "no time effect" is rejected, the time effect should be included in the model and the two-way fixed effect model should be chosen.

In this study, the mixed regression and random effect models were first used to analyze the factors influencing the economic security of water resources, followed by the LM Test. The test results showed that the random effect model was better than the mixed regression model. Then, the fixed effect model was used for regression, followed by the Hausman test. The results supported the fixed effect model. Finally, we tested the existence of a time effect; the results showed that the two-way fixed effect model should be used. Accordingly, the two-way fixed effect model was used in this study for analysis. Meanwhile, to obtain more credible research results, we further established a two-way fixed effect model using clustering robust standard errors. The estimated results of the mixed regression, random effect, fixed effect, and two-way fixed effect models are listed in columns (1)-(4) in Table 7.

According to Table 7(4), there was a U-shaped correlation between economic development $(\ln g d p)$ and the economic security of water resources, indicating that in the initial stage of economic development, the level of economic security of water resources in a country or region decreases with improvements to the economic development level; when the logarithm of the real per capita GDP is $>9.3155$, there is a promoting impact of economic development on the economic security of water resources. This shows that when the economic development of a country or a region is at a low level, it will lead to an increase in the demand for water resources and the discharge of wastewater and sewage, resulting in a low level of economic security of water resources. However, with economic level improvement, people gradually notice problems associated with environmental pollution and resource depletion resulting from economic development, thus changing the traditional concept of economic development, improving environmental protection awareness, and improving the efficiency of resource utilization through technological innovations and other paths, which will improve the level of economic security of water resources. There was a significant negative correlation between the population size (lnps) and economic security of water resources. Every $1 \%$ increase in the population will lead to an average decrease of $39 \%$ in the level of economic security of water resources. This indicates that a country or a region with a large population will inevitably observe an increase in the demand for water resources, which will threaten the quantity security and quality security of water resources, thus reducing the level of economic security of water resources. There was a significant negative correlation between the level of pollution control $(p l)$ and the economic security of water resources. Every unit decrease in the level of economic security of water resources will lead to an average increase of 247.4 in the pollution control level. There was a significant negative correlation between technological innovation $(t i)$ and the economic security of water resources. Although the value is small, the statistical significance is substantial. It implies that the process of technological development in China significantly hinders the level of economic security of water resources instead of improving it; China should constantly improve its direction of technological progress and protect against the rebound effect of technological innovation. Industrial structure advancement (iis) and industrial structure rationalization (irs) were both positively correlated with the economic security of 
water resources. Every unit increase in the advancement and rationalization of industrial structures increases the level of economic security of water resources by 3.390 and 2.866 , respectively. This indicates that the optimization and upgrade of China's industrial structure can promote the economic security of water resources. There was a negative correlation between the external coefficient ( $e f$ ) and the economic security of water resources. Every unit increase of the external coefficient leads to an average decrease of 1.853 in the level of economic security of water resources. This shows that China should be aware of water pollution caused by pollution intensive industries in international trade. There was a negative correlation between the scale of fixed asset investments ( fas) and the economic security of water resources. Every unit increase in the scale of fixed asset investments will yield a decrease in the average level of economic security of water resources by 1.689 . There was a positive correlation between human capital $(h c)$ and the economic security of water resources. Every unit increase in human capital level yields an average increase of 0.0006 in the level of economic security of water resources of China. With the increase in human capital, citizen awareness of environmental protection is gradually enhanced, the quantity and quality safety of water resources are guaranteed, and the sustainable development ability of water resources and level of economic security of water resources are improved.

\section{CONCLUSIONS AND IMPLICATIONS}

The economic security of water resources reflects the comprehensive state of economic development and water resources security of a country or a region. Reasonable analysis of the economic security level of water resources in a country or a region and its influencing factors is of great significance for the government to formulate environmental regulation policies, enhance regional green competitiveness, and realize the win-win situation of economic growth and resource-environmental protection. Based on the data of 30 provinces and cities in China from 2011 to 2017, this study evaluates the economic security level of water resources of each province and city based on the fuzzy comprehensive evaluation method, and empirically tests the influencing factors of economic security of water resources. The results show that the economic security level of water resources in China is fluctuating and rising, and it is gradually improving over time. The economic security level of water resources in three regions of China is different to some extent. In the central region it is the highest, followed by the western region, and the eastern region is the lowest. Further research shows that there is a U-shaped correlation between economic development and the economic security level of water resources, which first decreases and then increases, whereas there is a significant negative correlation between technological innovation and the economic security level of water resources. In addition, this study finds that with the optimization and upgrading of industrial structures and the improvement of human capital level, the economic security level of water resources will also be improved. Based on the aforementioned conclusions, we propose the following suggestions.

First, improve the regional utilization efficiency of water resources and promote regional economic security of water resources. It is found that the low level of water resources economic security in the eastern and western regions is mainly due to the lack of regional water resources and low utilization efficiency of water resources. Therefore, all regions should accelerate the construction of watersaving projects, improve water efficiency, promote the economical and intensive utilization of water resources, and ensure the economic security of regional water resources. Second, increase publicity and develop a green economy. Water pollution has eased to a certain extent with China's increased investment in pollution control; however, there are still several polluted rivers and lakes. The relevant departments should strengthen the publicity of environmental protection, improve the awareness of water resources protection, and promote the green and sustainable development of the economy. Third, accelerate the pace of technological innovation and protect against the rebound effect. In general, the emergence of new technologies can help improve the efficiency of water resources. However, the improvement of utilization efficiency may stimulate the relevant subjects to use more water, resulting 
Table 7. Effects of various factors on the economic security of water resources

\begin{tabular}{|c|c|c|c|c|}
\hline \multirow{3}{*}{ Variables } & (1) & (2) & (3) & (4) \\
\hline & OLS & RE & FE & FE_two \\
\hline & wes & wes & wes & wes \\
\hline $\ln 2 p g d p$ & $\begin{array}{l}-2.289 \\
(1.695)\end{array}$ & $\begin{array}{c}-0.396 \\
(1.720)\end{array}$ & $\begin{array}{l}3.774^{*} \\
(1.856)\end{array}$ & $\begin{array}{l}3.550 \\
(2.107)\end{array}$ \\
\hline $\ln p g d p$ & $\begin{array}{l}50.26 \\
(36.09)\end{array}$ & $\begin{array}{l}13.04 \\
(36.07)\end{array}$ & $\begin{array}{r}-70.23^{*} \\
(37.89)\end{array}$ & $\begin{array}{l}-66.14 \\
(42.74)\end{array}$ \\
\hline lnps & $\begin{array}{l}0.926 \\
(0.741)\end{array}$ & $\begin{array}{c}2.233 * * * \\
(0.769)\end{array}$ & $\begin{array}{c}-35.01 * * \\
(16.57)\end{array}$ & $\begin{array}{c}-39.00 * * \\
(18.37)\end{array}$ \\
\hline$p l$ & $\begin{array}{l}-233.3 \\
(226.1)\end{array}$ & $\begin{array}{c}-284.5^{* *} \\
(120.7)\end{array}$ & $\begin{array}{c}-385.0 * * * \\
(97.37)\end{array}$ & $\begin{array}{c}-247.4 * * \\
(111.6)\end{array}$ \\
\hline$t i$ & $\begin{array}{c}-2.60 \mathrm{e}-05^{* * *} * \\
(7.86 \mathrm{e}-06)\end{array}$ & $\begin{array}{c}-5.50 \mathrm{e}-05^{* * * *} \\
(1.23 \mathrm{e}-05)\end{array}$ & $\begin{array}{c}-7.17 \mathrm{e}-05^{* * * *} \\
(1.88 \mathrm{e}-05)\end{array}$ & $\begin{array}{c}-6.93 \mathrm{e}-05^{* * *} \\
(2.07 \mathrm{e}-05)\end{array}$ \\
\hline iis & $\begin{array}{l}0.0894 \\
(5.403)\end{array}$ & $\begin{array}{l}1.679 \\
(4.525)\end{array}$ & $\begin{array}{l}1.242 \\
(5.123)\end{array}$ & $\begin{array}{l}3.390 \\
(7.409)\end{array}$ \\
\hline irs & $\begin{array}{l}4.920 \\
(4.267)\end{array}$ & $\begin{array}{l}0.431 \\
\quad(5.534)\end{array}$ & $\begin{array}{l}-2.663 \\
(5.731)\end{array}$ & $\begin{array}{l}2.866 \\
(5.733)\end{array}$ \\
\hline$e f$ & $\begin{array}{r}-6.163^{*} \\
(3.061)\end{array}$ & $\begin{array}{l}-2.227 \\
(1.653)\end{array}$ & $\begin{array}{l}0.644 \\
(3.995)\end{array}$ & $\begin{array}{c}-1.853 \\
(3.529)\end{array}$ \\
\hline fas & $\begin{array}{c}-3.191 \\
(2.428)\end{array}$ & $\begin{array}{r}-2.123^{*} \\
(1.283)\end{array}$ & $\begin{array}{c}-3.805 * * * \\
(1.241)\end{array}$ & $\begin{array}{c}-1.689 \\
(1.193)\end{array}$ \\
\hline$h c$ & $\begin{array}{c}-0.000942 \\
(0.000602)\end{array}$ & $\begin{array}{r}-0.00173 * * \\
(0.000698)\end{array}$ & $\begin{array}{l}0.00146 \\
(0.00172)\end{array}$ & $\begin{array}{l}0.000565 \\
(0.00173)\end{array}$ \\
\hline Constant & $\begin{array}{l}-229.0 \\
(197.9)\end{array}$ & $\begin{array}{l}-57.27 \\
(193.0)\end{array}$ & $\begin{array}{r}657.6^{* * *} \\
(272.5)\end{array}$ & $\begin{array}{r}663.9 * * \\
(305.4)\end{array}$ \\
\hline Observations & 210 & 210 & 210 & 210 \\
\hline R-squared & 0.388 & 0.212 & 0.311 & 0.505 \\
\hline Number of ids & 30 & 30 & 30 & 30 \\
\hline LM test & {$[0.0000]$} & & & \\
\hline Hausman test & {$[0.0001]$} & & & \\
\hline Time-effect test & {$[0.0000]$} & & & \\
\hline
\end{tabular}

Note: robust standard errors in parentheses; ${ }^{* * *} p<0.01,{ }^{* *} p<0.05$, and ${ }^{*} p<0.1$; and P-value is in square brackets.

in waste of resources. It is therefore necessary for governments to consider the rebound effect when formulating policy. Fourth, optimize the industrial structure and enhance the level of human capital. Industrial structure optimization includes two aspects: upgrading and rationalization. Its aim is to realize the coordinated development of the industry and the optimal allocation of resources through industrial adjustment. Furthermore, the promotion of human capital has a positive impact on the economic security of water resources. Further improving the level of human capital and promoting the transformation and upgrading of industrial structures will help promote the high-quality development of a resource-economy.

However, the research on the economic security of water resources in this study must be developed. For example, the water resources economic security evaluation method can be further standardized. The input-output index system can be used for evaluation and analysis, and the results can be mutually verified with fuzzy comprehensive evaluation. In addition, it is also of great significance to introduce 
water resources economic security thresholds in different regions and divide them according to the water resources economic security level.

\section{ACKNOWLEDGMENT}

Xiaowei Ma and Yuanxiang Zhou contributed equally to this work and should be considered cocorresponding authors. This research is supported by the National Natural Science Foundation of China [grant numbers 71934001, 71471001, 71533004, and 41771568], National Social Science Foundation of China [grant number 20ZDA084], the National Key Research and Development Program of China [grant number 2016YFA0602500], the Ministry of Education in China [grant number 20YJC790193], and the Higher Education Institutions in Anhui Province of China [grant number KJ2020A0006]. 


\section{REFERENCES}

Ako, A. A., Eyong, G. E. T., \& Nkeng, G. E. (2010). Water resources management and integrated water resources management (IWRM) in Cameroon. Water Resources Management, 24(5), 871-888. doi:10.1007/ s11269-009-9476-4

Chang, Y. J., \& Zhu, D. M. (2021). Water security of the megacities in the Yangtze River basin: Comparative assessment and policy implications. Journal of Cleaner Production, 290, 17. doi:10.1016/j.jclepro.2021.125812

Du, J. S., Peng, S. F., Song, W., \& Peng, J. S. (2020). Relationship between enterprise technological diversification and technology innovation performance: Moderating role of internal resources and external environment dynamics. Transformations in Business \& Economics, 19(2), 52-73. doi:10.1177/0971721814561388

Fu, F. Y., Alharthi, M., Bhatti, Z., Sun, L. C., Rasul, F., Hanif, I., \& Iqbal, W. (2021). The dynamic role of energy security, energy equity and environmental sustainability in the dilemma of emission reduction and economic growth. Journal of Environmental Management, 280, 9. doi:10.1016/j.jenvman.2020.111828 PMID:33360740

Ginkel, K. C. H., Hoekstra, A., Buurman, J., \& Hogeboom, R. (2018). Urban water security dashboard: Systems approach to characterizing the water security of cities. Journal of Water Resources Planning and Management, 144(12), 04018075. Advance online publication. doi:10.1061/(ASCE)WR.1943-5452.0000997

Grey, D., \& Sadoff, C. W. (2007). Sink or swim? Water security for growth and development. Water Policy, 9(6), 545-571. doi:10.2166/wp.2007.021

Haider, H., Singh, P., Ali, W., Tesfamariam, S., \& Sadiq, R. (2015). Sustainability evaluation of surface water quality management options in developing countries: Multicriteria analysis using fuzzy UTASTAR method. Water Resources Management, 29(8), 2987-3013. doi:10.1007/s11269-015-0982-2

Li, B., Wang, X., Wei, T., Zeng, Y., \& Zhang, B. (2018). Analysis of sustainable utilization of water resources in karst region based on the ecological footprint model-Liupanshui city case. Journal of Water Supply: Research \& Technology - Aqua, 67(6), 566-575. doi:10.2166/aqua.2018.016

Li, B., Wu, Q., Zhang, W. P., \& Liu, Z. J. (2020). Water resources security evaluation model based on grey relational analysis and analytic network process: A case study of Guizhou Province. Journal of Water Process Engineering, 37, 7. doi:10.1016/j.jwpe.2020.101429

Mishra, B. K., Kumar, P., Saraswat, C., Chakraborty, S., \& Gautam, A. (2021). Water Security in a Changing Environment: Concept, Challenges and Solutions. Water (Basel), 13(4), 21. doi:10.3390/w13040490

Osei, J., Nyame, F. K., Armah, T. K., Osae, S. K., Dampare, S. B., Fianko, J. R. D., Adomako, N., \& Bentil, N. (2010). Application of multivariate analysis for identification of pollution sources in the Densu delta wetland in the vicinity of a landfill site in Ghana. Journal of Water Resource and Protection, 2(12), 1020-1029. doi:10.4236/ jwarp.2010.212122

Shi, Y. Y., Guo, S., \& Sun, P. Y. (2017). The role of infrastructure in China's regional economic growth. Journal of Asian Economics, 49, 26-41. doi:10.1016/j.asieco.2017.02.004

Song, M., Zhao, X., Shang, Y., \& Chen, B. (2020a). Realization of green transition based on the anti-driving mechanism: An analysis of environmental regulation from the perspective of resource dependence in China. The Science of the Total Environment, 698, 134317. doi:10.1016/j.scitotenv.2019.134317 PMID:31783437

Song, M., Ma, X., Shang, Y., \& Zhao, X. (2020b). Influences of land resource assets on economic growth and fluctuation in China. Resources Policy, 68, 101779. doi:10.1016/j.resourpol.2020.101779

Song, M., Zhao, X., \& Shang, Y. (2020c). The impact of low-carbon city construction on ecological efficiency: Empirical evidence from quasi-natural experiments. Resources, Conservation and Recycling, 157, 104777. doi:10.1016/j.resconrec.2020.104777

Staudinger, T. J., England, E. C., \& Bleckmann, C. (2006). Comparative analysis of water vulnerability assessment methodologies. Journal of Infrastructure Systems, 12(2), 96-106. doi:10.1061/(ASCE)1076-0342(2006)12:2(96)

Sun, D. L., Wu, J. P., Zhang, F. T., Su, W. C., \& Hui, H. (2018). Evaluating water resource security in karst areas using DPSIRM modeling, gray correlation, and matter-element analysis. Sustainability, 10(11), 16. doi:10.3390/ su10113934 
Sun, H. P., Ikram, M., Mohsin, M., \& Abbas, Q. (2021). Energy security and environmental efficiency: Evidence from oecd countries. The Singapore Economic Review, 66(2), 489-506. doi:10.1142/S0217590819430033

Van Leeuwen, C. J., Frijns, J., van Wezel, A., \& van de Ven, F. H. (2012). City blueprints: 24 indicators to assess the sustainability of the urban water cycle. Water Resources Management, 26(8), 2177-2197. doi:10.1007/ s11269-012-0009-1

Xenarios, S., Assubayeva, A., Xie, L., Sehring, J., Amirkhanov, D., Sultanov, A., \& Fazli, S. (2021). A bibliometric review of the water security concept in Central Asia. Environmental Research Letters, 16(1), 14. doi:10.1088/1748-9326/abc717

Yin, B., Guan, D., Zhou, L., Zhou, J., \& He, X. (2020). Sensitivity assessment and simulation of water resource security in karst areas within the context of hydroclimate change. Journal of Cleaner Production, 258, 120994. doi:10.1016/j.jclepro.2020.120994

Zhao, X., Shang, Y., \& Song, M. (2019a). Industrial structure distortion and urban ecological efficiency from the perspective of green entrepreneurial ecosystems. Socio-Economic Planning Sciences, 72, 100757. doi:10.1016/j. seps.2019.100757

Zhao, X., Shang, Y., \& Song, M. (2019b). What kind of cities are more conducive to haze reduction: Agglomeration or ex-pansion? Habitat International, 91, 102027. doi:10.1016/j.habitatint.2019.102027

Licheng Peng is a Ph.D. candidate in the School of Economics, Fujian Normal University. He focuses on Natural Resources and Economic Security.

Xiaowei Ma is a Ph.D. candidate in the School of Economics, Fujian Normal University, who has published papers in SCI/SSCl journals, such as Resources Policy, Environmental Science and Pollution Research, and Journal of Cleaner Production.

Wanwan Ma is a Master's degree Candidate in School of Management, Shanghai University, whose main research areas include Green Finance and Environmental Policy.

Yuanxiang Zhou is currently a Lecturer at the Institute of Statistics and Applied Mathematics, Anhui University of Finance and Economics. He received the Ph.D. degree in Statistics from Beijing Normal University, Beijing, China, in 2019. His research areas include National Economic Accounting and Environmental Economics. 